\title{
RXR acts as a coregulator in the regulation of genes of the hypothalamo-pituitary axis by thyroid hormone receptors
}

\author{
L Laflamme, G Hamann, N Messier, S Maltais and M-F Langlois \\ Department of Physiology and Medicine, Division of Endocrinology, Faculty of Medicine, University of Sherbrooke, CHUS, 3001, 12th Avenue North, \\ Sherbrooke, Quebec, Canada J1H 5N4 \\ (Requests for offprints should be addressed to M-F Langlois; Email: Marie-France.Langlois@Usherbrooke.ca)
}

\begin{abstract}
Thyroid hormone receptors (TRs) often modulate transcriptional activity of target genes by heterodimerization with the 9-cis retinoic acid receptor $(R X R)$. On positive thyroid response elements (TREs), RXR favors binding of the TR-RXR complex to DNA and stimulates transcription. RXR action on negative TREs is unclear. Furthermore, the single half-site configuration of many negative TREs does not favor the binding of a classic TR-RXR heterodimer. In a comparative study using CV-1 cells (relatively RXR- and TR-deficient) and JEG-3 cells (relatively TR-deficient), we demonstrate the importance of RXR in the negative transcriptional regulation of genes of the hypothalamo-pituitary axis by tri-iodothyronine. While RXR has variable effects on ligand-independent activation produced by TRs, it was required for efficient ligand-dependent repression of the TRH gene for TR $\alpha 1$ and TR $\beta 1$ and of the TSH genes by all TRs. Using different RXR constructs we also observed the importance of the C-terminus of RXR but not of the $\mathrm{N}$-terminus nor the DNA-binding domain, in the potentiation of negative regulation. We thus suggest that, with regard to negative regulation of the TRH and TSH genes by thyroid hormones, RXR behaves more like a cofactor than a classic heterodimerization partner.
\end{abstract}

Journal of Molecular Endocrinology (2002) 29, 61-72

\section{Introduction}

Thyroid hormones have very important metabolic and developmental effects in nearly all organ systems of the body. They exert most of their action at the genomic level, through binding to thyroid hormone receptors (TRs), which are well conserved transcription factors of the nuclear receptor superfamily (see Yen 2001 for review). The transcription of many genes is regulated by TRs, a good number of which have been studied in detail. Most of our current knowledge is based on the study of positively regulated genes, such as those for growth hormone (Glass et al. 1987), malic enzyme (Desvergne et al. 1991), $\mathrm{Na}^{+} / \mathrm{K}^{+}$-ATPase (Gick \& Ismail-Beigi 1990), sarcoplasmic endoplasmic reticulum $\mathrm{Ca}^{2+}$-ATPase (Hartong et al. 1994), and many others. In contrast, fewer genes are negatively regulated by tri-iodothyronine
$\left(\mathrm{T}_{3}\right)$, like those of the hypothalamo-pituitary axis: thyrotropin-releasing hormone (TRH) (Holenberg et al. 1995), thyrotropin (TSH) $\alpha$ (glycoprotein hormone common subunit) (Burnside et al. 1989) and TSH $\beta$ (Bodenner et al. 1991, Carr \& Wong 1994). The limited studies on these genes have demonstrated distinct features of negative regulation by thyroid hormone, such as ligandindependent activation (LIA) and $\mathrm{T}_{3}$-dependent repression (LDR) (Wondisford et al. 1989, Carr \& Wong 1994, Hollenberg et al. 1995). Moreover, negative regulation plays a pivotal role in thyroid hormone action as both TRH and TSH set the level of activity of the thyroid gland.

In vertebrates, TR isoforms derive from two genes: c-erbA $\alpha$ and c-erbA $\beta$ (Yen 2001). By alternative RNA splicing, c-erbA $\alpha$ gives rise to $\mathrm{TR} \alpha 1$ and the c-erbA $\alpha 2$ protein, which does not bind $\mathrm{T}_{3}$ (Koenig et al. 1989, Katz \& Koenig 1994, 
Liu et al. 1995). Using alternative 5' exons and separate promoters, TR $\beta 1$ and TR $\beta 2$ are derived from the c-erbA $\beta$ locus (Hodin et al. 1989, Wood et al. 1994). TR $\beta$ isoforms differ structurally only in their amino-terminal domain, which derive from distinct exons and are completely different. TR $\beta 2$ expression is restricted to the pituitary (Hodin et al. 1989) and hypothalamus (Lechan et al. 1994), although low mRNA and protein levels have been found in other parts of the central nervous system and some peripheral tissues (Lechan et al. 1993, Schwartz et al. 1994, Li \& Boyages 1996). This is in contrast to other TR isoforms which have ubiquitous expression (Sakurai et al. 1989, Schwartz et al. 1992). It has previously been shown that $\mathrm{TR} \beta 2$ plays a unique role in negative regulation by thyroid hormone. It is the only TR isoform to achieve significant LIA of the TRH and TSH $\alpha$ genes and LDR of the TRH gene (Langlois et al. 1997). The TR $\beta 2$ knockout mice confirm the importance of this isoform for in vivo regulation of the hypothalamo-pituitary axis (Abel et al. 2001).

The 9-cis retinoic acid receptor ( $\mathrm{RXR})$, another member of the nuclear receptor superfamily, is a major heterodimeric partner for many nuclear receptors, including TRs, and serves as a modulator of their transcriptional regulation (see Mangelsdorf \& Evans 1995 for review). There are three human RXR isoforms: $\operatorname{RXR} \alpha, \operatorname{RXR} \beta$ and RXR $\gamma$ (Hamada et al. 1989, Mangelsdorf et al. 1990, Leid et al. 1992, Mangelsdorf et al. 1992). $\operatorname{RXR} \gamma$ is of particular interest in the study of negative regulation since, in contrast to mRNA of the other isoforms, which are widely expressed, $\mathrm{RXR} \gamma$ expression is restricted to a few tissues and is predominant in TSH-producing cells of the pituitary gland (Sugawara et al. 1995, Haugen et al. 1997, Sanno et al. 1997). RXR $\alpha$ is also expressed at high levels in the human pituitary (Sanno et al. 1997), where RXR $\beta$ was not found, although it is expressed in rat pituitary tissue (Sugawara et al. 1995, Sanno et al. 1997).

The role of RXR in the context of positively regulated genes has been extensively studied. RXR enhances stimulatory $\mathrm{T}_{3}$ responses from positive thyroid response elements (pTREs) and facilitates DNA binding (Rosen et al. 1992, Zhang et al. 1992, Leng et al. 1994, Hsu et al. 1995, Nelson et al. 1996). However, the effect of RXR on negative thyroid response elements (nTREs) has not been the subject of thorough investigation. Haugen et al.
(1997) have shown that $\mathrm{RXR} \gamma$ is necessary to suppress TSH $\beta$ promoter activity in TtT-97 thyrotropic tumor cells, suggesting an important role in negative regulation. In this study, we demonstrate the importance of RXR in the regulation of the genes of the hypothalamopituitary axis by thyroid hormone. Using different RXR constructs we also demonstrate that the function of RXR in negative regulation is located in its $\mathrm{C}$-terminus and does not involve its binding to DNA. We thus suggest that RXR acts more like a cofactor than a classic heterodimerization partner, in the context of negative regulation by thyroid hormone. These results emphasize the importance of RXR, not only on positively regulated genes but also on negative regulation by thyroid hormones.

\section{Materials and methods}

\section{Plasmid construction}

The cDNAs of human (h) TR $\alpha 1$, hTR $\beta 1$, hTR $\beta 2$ (Fig. 1A), hRXR $\alpha$, hRXR $\beta$, hRXR $\gamma$ (Fig. 4A) and hRAR (Fig. 6A) were inserted into pSG5 (Stratagene, La Jolla, CA, USA), which is the expression vector used for all receptor constructs utilized in this report (Breathnach \& Harris 1983). The RXR- $\Delta \mathrm{C}$ mutant (Fig. 6A) was created by deleting the amino acids 402-462 of hRXR $\alpha$ with the StuI restriction enzyme. RXR E453A (Fig. 6A) was produced by using an in vitro mutagenesis kit (Promega) and a mutagenesis primer that changed the glutamic acid to alanine at codon 457 in the AF-2 region. The RAR-RXR construct (Fig. 6A) was generated from hRAR for which the C-terminus had been swapped for $h R X R \alpha$ C-terminus. GAL4 and GAL4-RXR encode amino acids 1-147 of GAL4 DNA-binding sequence alone or fused to the $\mathrm{C}$-terminus of hRXR $\alpha$ (amino acids 188-462), in the pBXG1 vector which contains the GAL4 nuclear localization signal; for cloning purposes an EcoRI site has been introduced in frame, by PCR, just $3^{\prime}$ to the DNA-binding domain of $\operatorname{RXR} \alpha$, and the PCR product is introduced in frame in the EcoRI site of the vector. Mutating the first zinc finger of the DNA-binding domain of TR $\beta 1$ for the corresponding glucocorticoid receptor sequence created the TR $\beta 1-D N A$ binding mutant (TR $\beta 1-\mathrm{DBM})$.

The nTRE reporter constructs included the 5 '-flanking sequences from the human TRH 
(-900/+55) (Hollenberg et al. 1995), the common glycoprotein $\alpha$-subunit (TSH $\alpha,-846 /+26)$ and the TSH $\beta$-subunit (TSH $\beta,-125 /+37$ ) (Chatterjee et al. 1989, Bodenner et al. 1991) fused upstream of a luciferase reporter gene (PSVO or PGL3 vector). The RARE3 reporter contains 3 copies of an idealized retinoic acid response element (RARE) fused to luciferase in the PSVO vector (Kurlandsky et al. 1994).

\section{Cell culture and transfection assays}

The CV-1 (African green monkey renal carcinoma, ATCG, Manassas, VA, USA) and JEG-3 (human choriocarcinoma, ATCG) cell lines were maintained in DMEM supplemented with 10\% FBS, penicillin, streptomycin, and amphotericin (Gibco BRL). Transient transfections were realized in 6-well plates on subconfluent cells using the calcium-phosphate technique. Each experiment utilizes $1.6 \mu \mathrm{g}$ reporter construct and $80 \mathrm{ng}$ of each receptor expression vector or vector alone per well. Sixteen hours after transfection, culture medium is replaced by medium containing FBS stripped of hormone by anion-exchange resin and charcoal, and with or without $10 \mathrm{nM} \mathrm{T}$. Thirty-six to forty hours after transfection, cells are harvested and assayed for luciferase activity. Data are from at least three independent experiments performed in triplicate, and are displayed as means \pm s.E.

\section{RNA isolation and analysis}

Total RNA was isolated either from CV-1 or JEG-3 cells using the TRIzol Reagent (Sigma). Ten micrograms glyoxylated RNA were electrophoresed on a $1 \%$ agarose gel and analyzed by Northern blot hybridization. The blot was hybridized with a ${ }^{32} \mathrm{P}$-random labeled cDNA probe for a common region of the different isoforms of $h R X R$ generated using a Ndel-Pstl fragment of hRXR $\alpha$. The blot was stripped and hybridized with a probe for human glyceraldehyde-3-phosphate dehydrogenase (hGAPDH), for loading control.

\section{Immunoprecipitation and immunoblotting}

CV-1 cells grown in 100-mm Petri dishes were transfected with $500 \mathrm{ng}$ hTR $\beta 1$ and hRXR $\alpha$. Cells were lysed in $10 \mathrm{mM}$ Tris, $10 \mathrm{mM} \mathrm{NaCl}, 3 \mathrm{mM}$ $\mathrm{MgCl}_{2}, 0 \cdot 5 \% \mathrm{NP} 40$ and centrifuged at $500 \times \mathbf{g}$ for $10 \mathrm{~min}$. The pellet was resuspended in nuclear extract buffer $(15 \mathrm{mM}$ Tris, $60 \mathrm{mM} \mathrm{KGl,} 15 \mathrm{mM}$ $\mathrm{NaCl}, 1 \mathrm{mM}$ EDTA, $0.2 \mathrm{mM}$ EGTA, $1 \mathrm{mM}$ $\mathrm{CaCl}_{2}, 10 \mathrm{mM} \quad \mathrm{MgCl}_{2}, \quad 0 \cdot 5 \%$ SDS). Immunoprecipitation was performed using a polyclonal antibody to the full length thyroid hormone receptor of chicken origin (anti-TR $\alpha 1$ FL-408: sc-772; Santa Cruz Biotechnology, Santa Cruz, CA, USA), recognizing TR $\alpha 1$ and TR $\beta 1$ of mouse, rat human and chicken origin. After overnight incubation of sample at $4{ }^{\circ} \mathrm{C}$ with rocking, protein $\mathrm{G}$-sepharose was added, and samples were rocked for $2 \mathrm{~h}$ at $4{ }^{\circ} \mathrm{C}$. After five washes with nuclear extract buffer without detergent, proteins were resolved on a 10\% SDS-polyacrylamide gel and transferred to a polyvinylene difluoride membrane. The membrane was blocked with $1 \%$ gelatin, $0.05 \%$ Tween 20 in TBS buffer, $\mathrm{pH} 7.5$ and incubated overnight at $4{ }^{\circ} \mathrm{C}$ with constant agitation with a monoclonal anti-TR $\alpha$ l (C4) antibody (sc-740; Santa Cruz Biotechnology). This antibody reacts with both TR $\alpha 1$ and TR $\beta 1$ of human origin. The membrane was washed with TBS/Tween 20. Detection was accomplished using horseradish peroxidase-conjugated anti-mouse antibody (Amersham, Canada) and enhanced chemiluminescence detection system (Roche Molecular Biochemicals, Canada).

RXR protein expression was analyzed using $75 \mu \mathrm{g}$ of nuclear extracts of CV-1 or JEG-3 cells. Proteins were electrophoresed on a $12 \%$ SDSpolyacrylamide gel and immunoblotted using an anti-RXR $\alpha$ antibody (sc-774; Santa Cruz Biotechnology), recognizing all RXR isoforms: $\mathrm{RXR} \alpha$, $\operatorname{RXR} \beta$ and RXR $\gamma$. The different RXR isoforms used as controls were made by in vitro translation in rabbit reticulocyte lysate (TNT kit, Promega) using $\mathrm{RXR} \alpha, \operatorname{RXR} \beta$ or RXR $\gamma \mathrm{cDNAs}$ in pSG5 and T7 polymerase.

\section{Results}

\section{$R X R$ is a cell-specific factor enhancing negative regulation}

To investigate the role of RXR in negative regulation by thyroid hormone, we first studied the regulation of nTREs in two cell lines: $\mathrm{CV}-1$ and JEG-3. The effect of TRs on negatively regulated genes has two components: LIA and LDR. Since it was previously shown that TR isoforms have variable actions on nTREs (Langlois et al. 1997, 
Safer et al. 1997), the three isoforms were studied separately and are schematically represented in Fig. 1A.

In $\mathrm{CV}-1$ cells, TR $\beta 2$ produced a higher LIA than TR $\alpha 1$ and TR $\beta 1$ on the TRH reporter (Fig. $1 \mathrm{~B})$. TR $\beta 2$ was also the only isoform to produce significant LDR (Fig. 1B and C). Cotransfection of RXR $\alpha$ in these cells was beneficial for LIA of $\mathrm{TR} \alpha 1$ and $\mathrm{TR} \beta 1$ receptors and increased the negative regulation of the $\mathrm{TRH}$ reporter by all three TR isoforms (Fig. 1B and G). Interestingly, repression of the TRH reporter under transcriptional levels reached with the pSG5 vector alone was only achieved in the presence of RXR $\alpha$ (Fig. 1B). Overexpression of RXR $\alpha$ in $\mathrm{CV}-1$ cells had no influence on the TR expression levels compared with cells transfected only with TR $\beta 1$, as shown by Western blot experiment (Fig. 2A).

Transcriptional regulation by TRs was different in JEG-3 cells as compared with $\mathrm{CV}-1$ cells. Individual LIA produced by TR $\alpha 1$ and TR $\beta 1$ were similar in both cell lines, while TR $\beta 2$ failed to produce any significant LIA in JEG-3 cells (Fig. 1D). All three isoforms were able to repress transcription of the TRH reporter in the presence of $\mathrm{T}_{3}$ (Fig. 1D and E). The fold repression observed in RXR $\alpha$-transfected $\mathrm{CV}-1$ cells reached comparable levels to those obtained with JEG-3 cells, except for the TRal receptor (Fig. $1 \mathrm{C}$ and $\mathrm{E}$ ).

Evaluation of the RXR content of JEG-3 and GV-1 cells by Northern and Western blot experiments revealed a high endogenous expression of RXR $\alpha$ in JEG-3 cells, whereas CV-1 cells contained no detectable RXR mRNA or protein (Fig. 2B and G). This is consistent with a previous report showing that RXR $\alpha$ is the major isoform expressed in JEG-3 cells (Guibourdenche et al. 1998).

The overexpression of RXR $\alpha$ in JEG-3 cells abolished the LIA of all three TR isoforms and, in contrast to CV-1 cells, repression in the presence of $\mathrm{T}_{3}$ was not increased by cotransfection of $\mathrm{RXR} \alpha$ (Fig. 1D and E). Lowering of the transcriptional activities seen in JEG-3 cells overexpressing RXR $\alpha$ suggest a squelching effect of the transcriptional machinery.

On the TSH $\alpha$ reporter, TR $\beta 2$ is the only isoform to produce significant LIA in the absence of RXR, reaching $1 \cdot 38$-fold activation compared with $1 \cdot 12$ - and $1 \cdot 14$-fold for TR $\alpha 1$ and TR $\beta 1$ (Fig. $3 \mathrm{~A})$. RXR $\alpha$ cotransfection is needed to increase
LIA and LDR of all TR isoforms (Fig. 3A and B). Similar results are obtained for the TSH $\beta$ reporter (Fig. 3C and D), suggesting that RXR is important for the regulation of all nTREs. In JEG-3 cells, $\mathrm{TSH} \alpha$ and TSH $\beta$ reporters are negatively regulated by all TR isoforms and transcription is not significantly modified by cotransfection of RXR (data not shown). Altogether, these results demonstrate the importance of RXR in negative regulation of genes of the hypothalamo-pituitary axis, especially by $\operatorname{TR} \alpha 1$ and $\operatorname{TR} \beta 1$.

\section{Potency of RXR isoforms}

In Fig. 4A a schematic representation of the different RXR isoforms is shown. On a retinoic acid response element (RARE), all RXR isoforms produce similar activation of transcription in the presence of 9-cis retinoic acid (Fig. 4B). There is also transactivation with the pSG5 vector alone, suggesting the presence of endogenous RAR in CV-1 cells.

All three RXR isoforms greatly increase the efficiency of $\mathrm{T}_{3}$-mediated repression of the TRH gene (Fig. 5A). Furthermore, because TSH $\alpha$ and TSH $\beta$ genes are expressed in the pituitary in vivo and could be regulated differently from TRH (expressed in the hypothalamus), especially by $\operatorname{RXR} \gamma$, we found it important to compare the function of RXR isoforms on these genes. On TSH $\alpha$ and TSH $\beta$ nTREs, all RXR isoforms enhance negative regulation, but $\mathrm{RXR} \beta$ is slightly weaker in this respect (Fig. 5B and $\mathrm{C}$ ).

\section{The C-terminus of RXR is necessary for its action}

It is known from previous work that RXR heterodimerizes with TR through its C-terminal $\mathrm{EF}$ domain and the importance of this interaction was evaluated as regard to positive regulation (Leng et al. 1994). We aimed to identify the areas of RXR that are necessary for negative regulation, and to do so we designed a series of RXR mutants that are represented in Fig. 6A. Transfection data using these RXR mutants are shown in Fig. 6B. We determined that a carboxy-terminal deletion mutant of RXR lacking the heterodimerization domain (RXR- $\Delta \mathrm{C}$ ) lost its ability to enhance repression of the TRH reporter. However, a mutation of the AF-2 domain of RXR (E453A) 
A $\mathrm{N}$-Terminus

C-Terminus
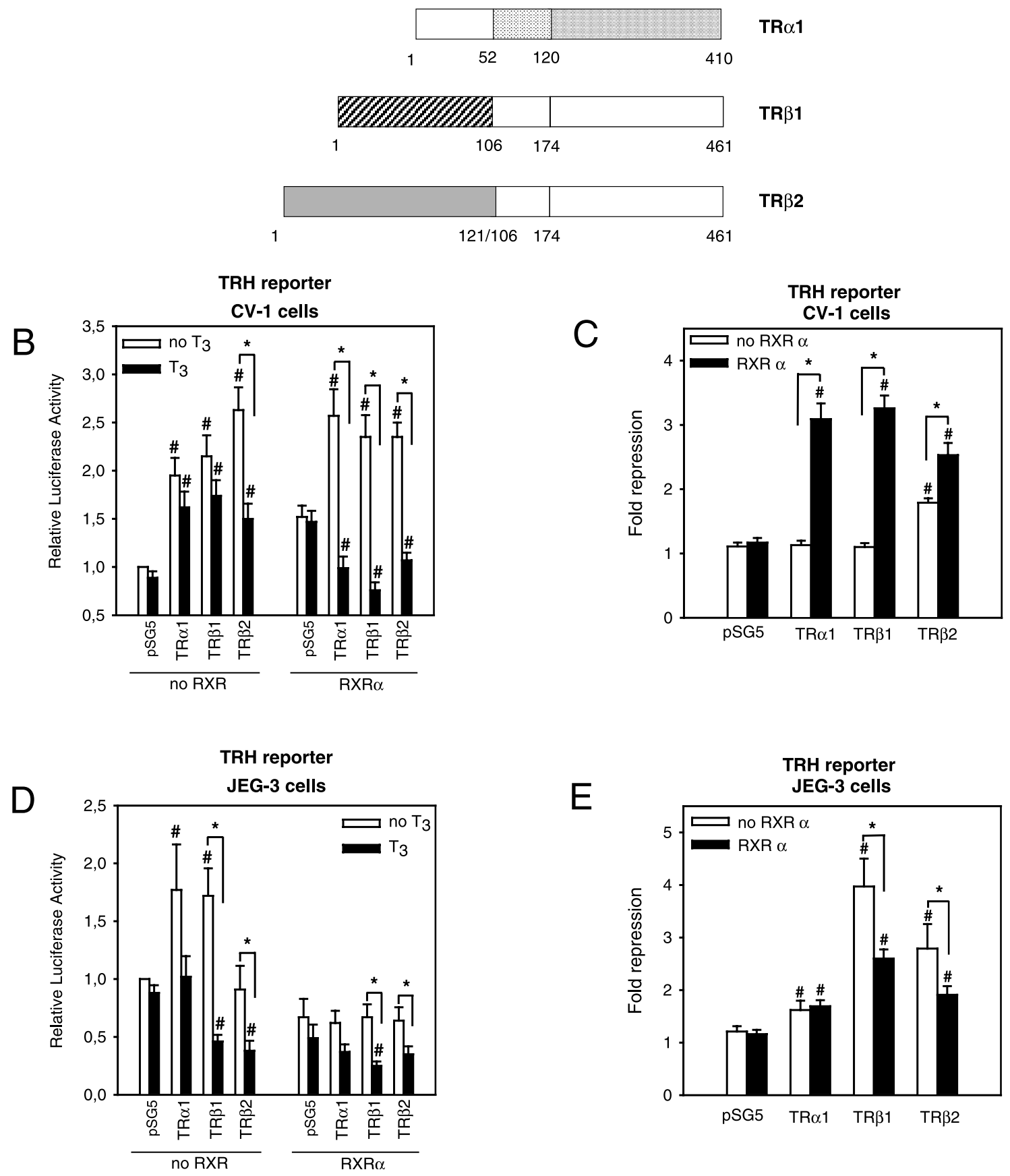

Figure $1 R X R$ is a cell-specific factor enhancing negative regulation. (A) Schematic representation of the human thyroid hormone receptor (TR) isoforms used in these studies. (B) and (C) Effect of TR isoforms and $R X R \alpha$ on transcriptional regulation of the TRH reporter, in the absence and presence of $T_{3}$, in CV-1 cells. (D) and (E) Effect of TR isoforms and RXR $\alpha$ on transcriptional regulation of the TRH reporter, in the absence and presence of $\mathrm{T}_{3}$, in JEG-3 cells. The data are expressed in fold repression or in relative activity, compared with the empty pSG5 vector in the absence of $T_{3}$, \pm S.E.M. An asterisk indicates that the difference between the pairs denoted is significant at a confidence level of $P \leq 0.05$ by Student's $t$-test. A \# indicates that the difference from the control is significant at a confidence level of $P \leq 0.05$ by Student's $t$-test. 


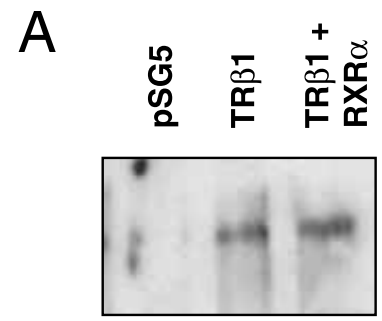

IP TR (FL408)

IB TR (C4)

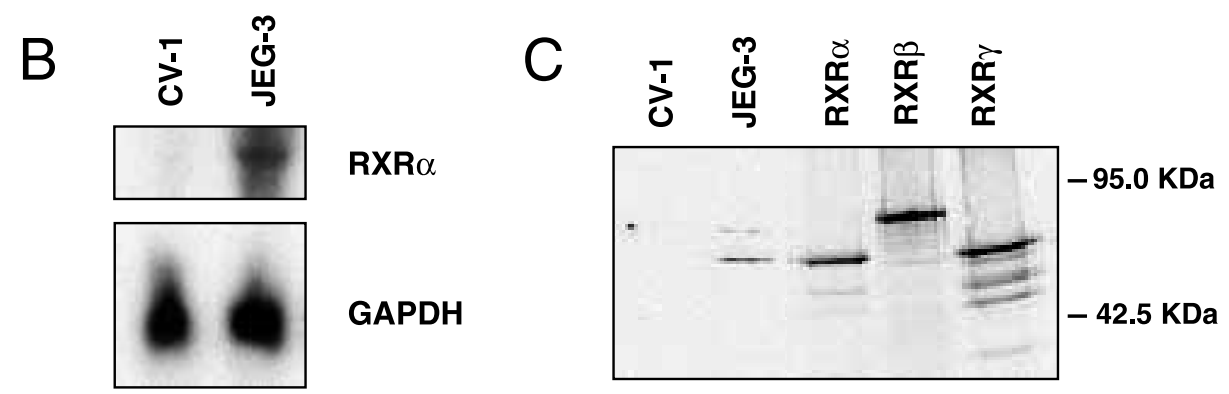

Figure 2 (A) Western blot analysis of immunoprecipitated TR from CV-1 cells. TRs immunoprecipitated (IP) with rabbit TR specific antibody FL408 were immunoblotted (IB) using mouse TR specific antibody C4. (B) Northern blot analysis of RXR expression in CV-1 and JEG-3 cells. The blot was sequentially hybridized with a cDNA probe made from a fragment of RXR $\gamma$ common to all $\mathrm{RXR}$ isoforms, and a hGAPDH cDNA probe. (C) Western blot analysis of RXR from nuclear extracts of $\mathrm{CV}-1$ and JEG-3 cells. RXR $\alpha, \mathrm{RXR} \beta$ and $\mathrm{RXR} \gamma$ proteins made by in vitro translation in rabbit reticulocytes were used as controls to confirm the recognition of all RXR isoforms by the antibody.

does not affect its function. RAR is not a classic heterodimeric partner of TRs and, by itself, produced no effect on negative regulation in our system. In contrast, the RAR-RXR chimera in which the EF domain of RXR is fused to the A-D domains of RAR shows a similar increase of repression by $\mathrm{T}_{3}$ as compared with $\mathrm{RXR} \alpha$. These data indicate that the heterodimerization domain of RXR is required to enhance negative regulation by $\mathrm{T}_{3}$ and further suggests the notion that the DNA-binding domain of RXR is not necessary to mediate its action.

\section{Negative regulation by thyroid hormone requires TR, but not RXR DNA-binding}

To confirm that RXR could enhance negative regulation in the absence of its DNA-binding and amino-terminal domains, we designed an RXR construct in which the C-terminus of RXR was fused to a heterologous GAL4 DNA-binding domain in an expression vector that ensures nuclear localization. This RXR $\alpha$-GAL construct produces repression comparable to that of $\operatorname{RXR} \alpha$ wild type (wt) on the TRH reporter and also on TSH $\alpha$ and TSH $\beta$ reporters (Fig. 7A). The GAL4 DNA-binding domain being unable to recognize TREs, our results suggest that the C-terminus of RXR is sufficient to mediate negative regulation and that it functions without forming a classic heterodimer on the nTRE.

Since the DNA-binding domain of RXR was facultative, we then generated a TR $\beta 1$ construct without DNA-binding properties (TR $\beta 1-\mathrm{DBM})$ to investigate the possibility of the effect occurring in solution. The results presented in Fig. 7B clearly show that TR $\beta 1$ binding to the TRH nTRE is essential for negative regulation of this gene, as the TR $\beta 1$-DBM does not induce repression either in the presence or absence of RXR $\alpha$. Similar results are obtained with the TSH $\alpha$ and TSH $\beta$ genes (data not shown). 
TSH $\alpha$ reporter

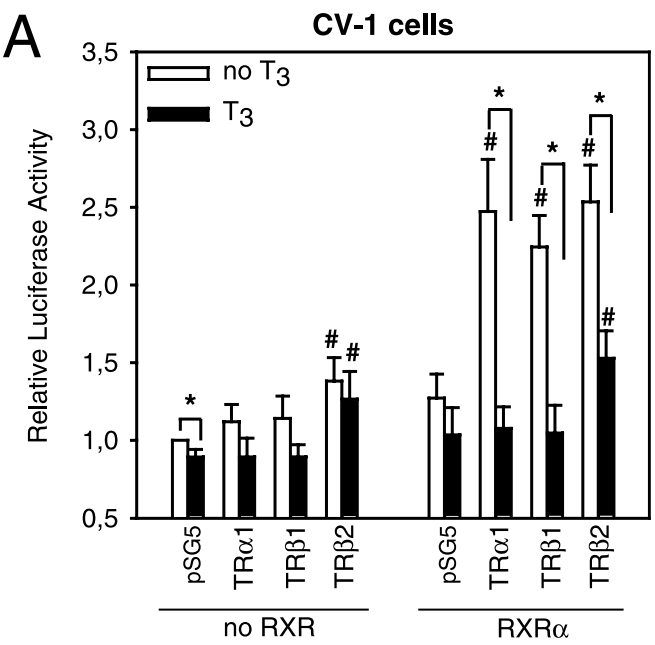

TSH $\beta$ reporter

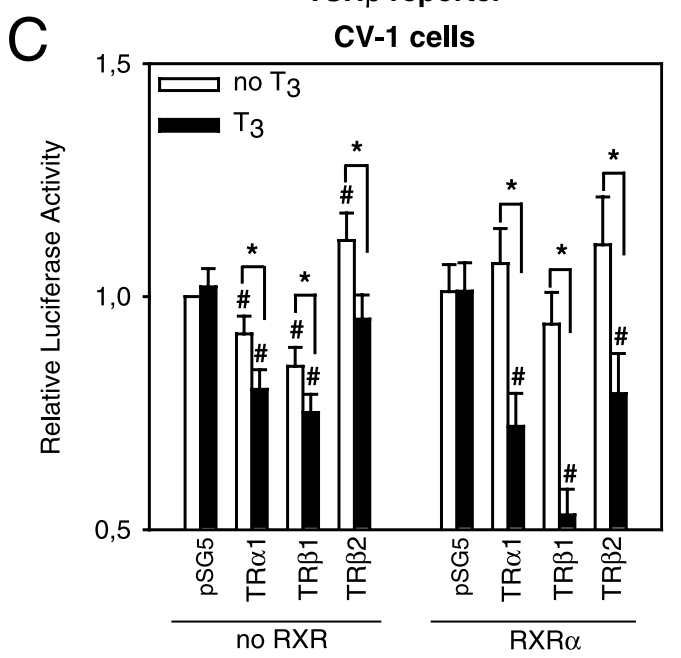

B

TSH $\alpha$ reporter

CV-1 cells
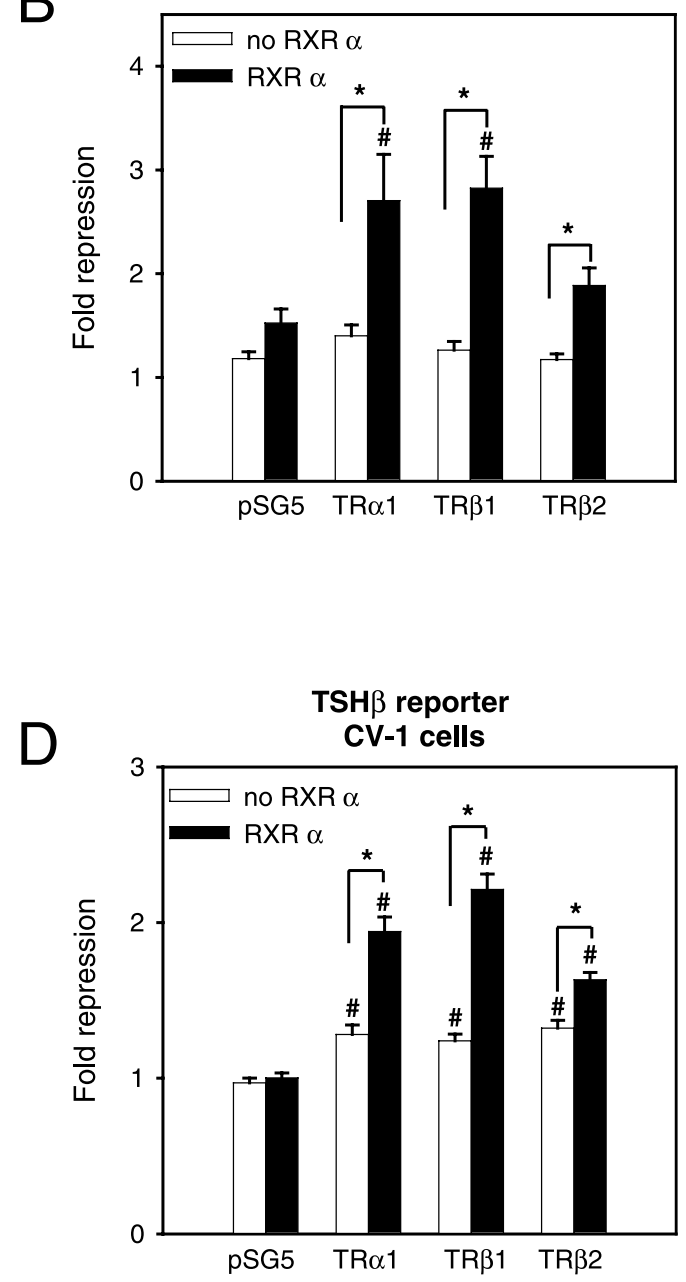

Figure 3 Importance of RXR in thyroid hormone regulation of TSH $\alpha$ and TSH $\beta$ genes. Effect of TR isoforms and $R X R \alpha$ cotransfected in CV-1 cells on the regulation of (A) and (B) the TSH $\alpha$ reporter, and (C) and (D) the TSH $\beta$ reporter. The data are expressed in fold repression or relative activity, compared with pSG5 alone without $T_{3}, \pm$ S.E.M. An asterisk indicates that the difference between the pairs denoted is significant at a confidence level of $P \leq 0.05$ by Student's $t$-test. A \# indicates that the difference from the control is significant at a confidence level of $P \leq 0.05$ by Student's $t$-test.

\section{Discussion}

The importance of $\mathrm{RXR}$ in the regulation of positive thyroid hormone response elements has been well demonstrated. On pTREs, RXR binds a half site of the TRE and increases TR DNAbinding and transactivation potency (Rosen et al. 1992, Zhang et al. 1992, Leng et al. 1994, Hsu et al. 1995, Mangelsdorf \& Evans 1995, Nelson et al.
1996). However, the role of RXR in the regulation of nTREs has been less studied. The configuration of many nTREs does not favor the binding of a classic TR-RXR heterodimer since they often bear a single consensus half site, which implies that only the TR would be able to bind DNA as a monomer. In this report we indicate the importance of RXR in the negative regulation of genes of the hypothalamo-pituitary axis. We also propose a 
A

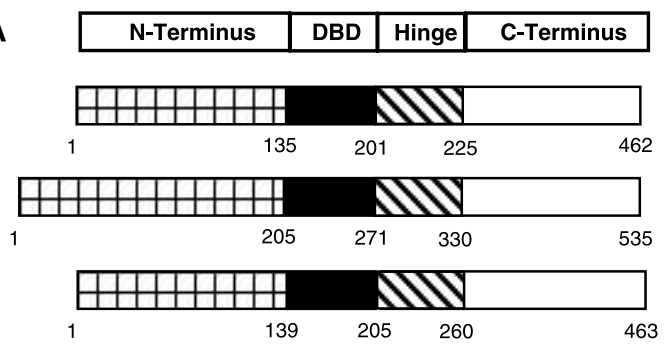

B

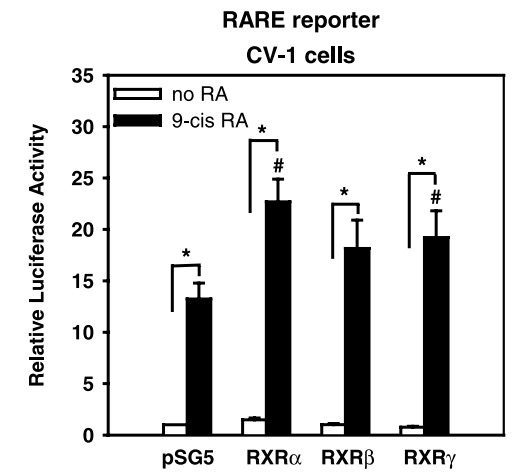

Figure 4 Comparison of $R X R$ isoforms on a retinoic acid response element (RARE). (A) Schematic representation of 9-cis retinoic acid receptor $(R X R)$ isoforms. (B) Effect of empty vector pSG5 and RXR isoforms on an idealized RARE reporter, in the absence and presence of 9-cis retinoic acid (9-cis RA). The data are expressed in relative activity, compared with pSG5 empty vector without $T_{3}, \pm$ S.E.M. An asterisk indicates that the difference between the pairs is significant with a confidence level of $P \leq 0.001$ by Student's $t$-test. A \# indicates that the difference from the control is significant at a confidence level of $P \leq 0.05$ by Student's $t$-test.

novel model of interaction between TRs and RXR on negative thyroid hormone response elements naturally found in the TRH and TSH genes.

The results we obtained on negatively regulated promoters show that RXR $\alpha$ enhances the LIA of the TSH genes by all three TR isoforms. On the TRH gene, RXR $\alpha$ is beneficial for the LIA produced only by the TR $\alpha 1$ and TR $\beta 1$ isoforms, suggesting a distinct mode of regulation of this promoter. Furthermore, as opposed to the TSH genes, absolute repression of the TRH gene, under levels reached with the pSG5 vector alone was obtained only when $\operatorname{RXR} \alpha$ was expressed. For all the negatively regulated genes of the hypothalamopituitary axis studied, $\operatorname{RXR} \alpha$ accentuates fold repression by every $\mathrm{TR}$, therefore acting as an
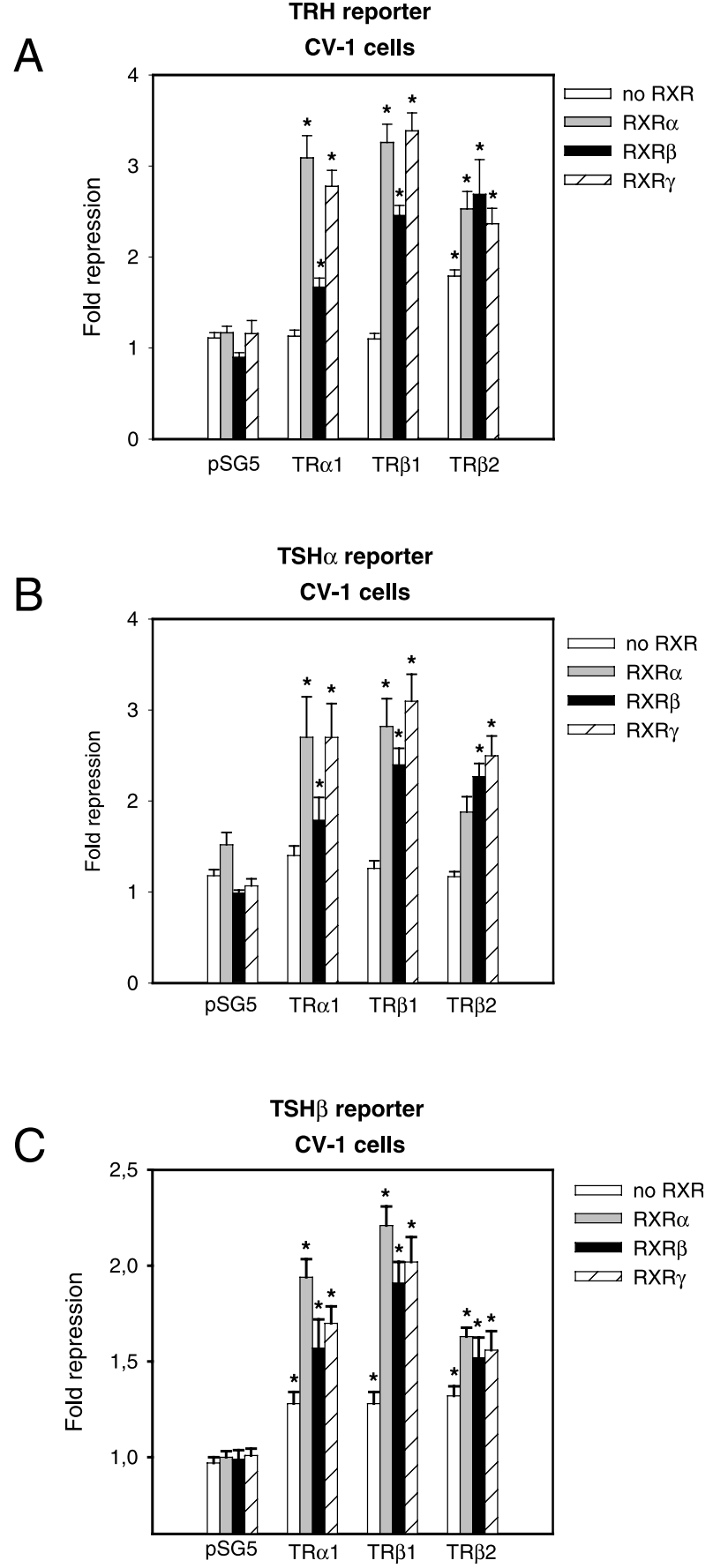

Figure 5 Comparison of RXR isoforms in negative regulation by thyroid hormone. Fold $\mathrm{T}_{3}$-induced repression by TR isoforms in conjunction with $R X R$ isoforms on (A) the TRH reporter, (B) the TSH $\alpha$ reporter and (C) the TSH $\beta$ reporter, in CV-1 cells. The data are expressed in fold repression \pm S.E.M. An asterisk indicates that the difference from the control is significant at a confidence level of $P \leq 0.05$ by Student's $t$-test. 
A
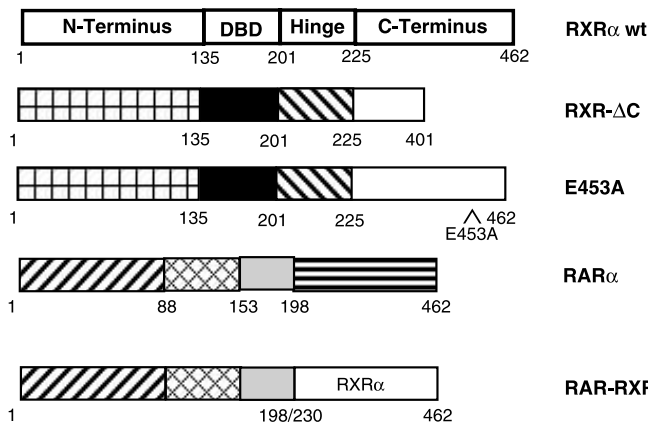

RAR-RXR $\alpha$

B

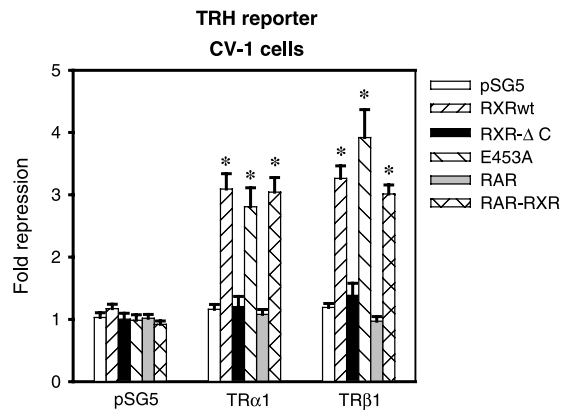

Figure 6 The C-terminus of RXR is necessary to mediate its action. (A) Schematic representation of RXR mutants utilized in these studies. (B) Effect of RXR and RAR wt and constructs on fold $T_{3}$-induced repression of the TRH reporter, in CV-1 cells. The data are expressed in fold repression \pm S.E.M. An asterisk indicates that the difference from the control is significant with a confidence level of $P \leq 0.001$ by Student's $t$-test. important transcriptional regulator. In the absence of RXR, TR $\beta 2$ behaves differently from TR $\alpha 1$ or TR $\beta 1$. On the TRH gene, TR $\beta 2$ was the only isoform to show significant LDR whereas on the TSH genes, it was unique in showing LIA. Different behavior of this receptor on negative regulation may derive from its distinct aminoterminus, interacting either differently with known coregulators or with new cofactors (Langlois et al. 1997, Yang et al. 1999).

While we have shown that RXR is an important cell-specific factor for the regulation of TRH, TSH $\alpha$ and TSH $\beta$ genes, two other groups have come to different conclusions based on studies realized in other experimental conditions. Indeed, Hallenbeck et al. (1993) and Carr and Wong (1994) have reported that RXR inhibits negative regulation by $\mathrm{T}_{3}$. However, they have not excluded an artifact in their CAT assay. Also, another group has shown that RXR had no effect on negative regulation of the $\mathrm{TSH} \alpha$ promoter by $\mathrm{TR} \beta 1 \mathrm{wt}$ (Takeda et al. 1997). However, experiments were conducted in JEG-3 cells already expressing RXR at high level, which may have caused squelching of the effects, as we observed in our own experiments with JEG-3 cells (Fig. 1D and E). Our results are in agreement with those of Haugen et al. (1997) who have shown the importance of $\operatorname{RXR} \gamma$ in
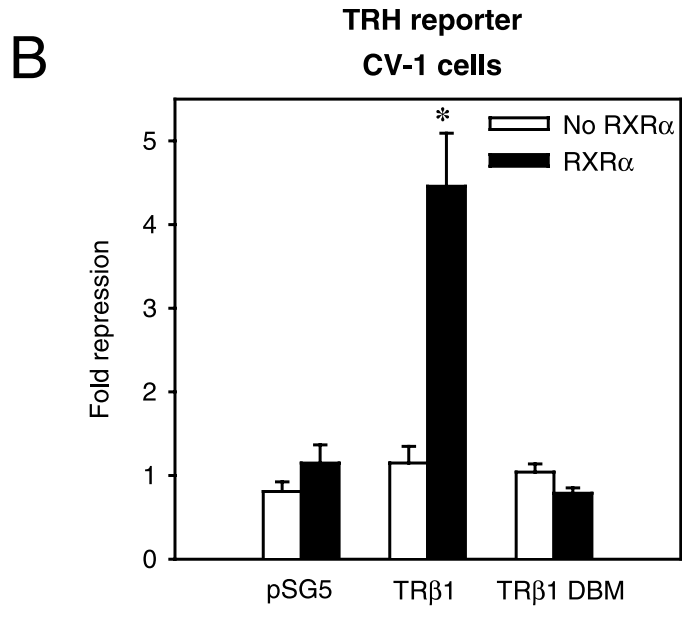

Figure 7 Negative regulation by $T_{3}$ requires DNA binding of TR but the C-terminus of RXR is sufficient to mediate its action. (A) Effect of RXR $\alpha$ and GAL-RXR on $T_{3}$-induced repression (fold) by TR $\beta 1$ of the TRH reporter in CV-1 cells. The data are expressed in relative activity, compared with GAL empty vector without $T_{3}, \pm$ S.E.M. (B) Effect of TR $\beta 1$ wt and TR DNA-binding mutant (DBM), in the absence and presence of RXR on fold $\mathrm{T}_{3}$-induced repression of the TRH reporter. The data are expressed in fold repression \pm S.E.M. An asterisk indicates that the difference from the control is significant with a confidence level of $P \leq 0.05$ by Student's $t$-test. 
suppressing TSH $\beta$ promoter activity and thus strongly suggest an important role for RXR in the regulation of the hypothalamo-pituitary axis.

Since RXR isoforms are expressed from three different genes, denoted $\alpha, \beta$ and $\gamma$, we have also examined the role of each different human RXR isoform. $\operatorname{RXR} \alpha$ and $\operatorname{RXR} \gamma$ were found to be equally potent in enhancing negative regulation while RXR $\beta$ was less efficient. This question has less physiological relevance since $\mathrm{RXR} \beta$ was not shown to be expressed in human pituitary tissues (Sanno et al. 1997).

Our results strongly suggest a very novel mechanism of action for RXR in which the carboxy-terminal end is essential and sufficient for its action (Figs 6 and 7A). This implies that the RXR portion of the heterodimer does not need to bind the response element and acts more as a coregulator. To our knowledge, it is the first time that such a mechanism of action for RXR has been suggested, and this is consistent with the known configuration of nTREs. In contrast to pTREs, which are always composed of two half-sites, most nTREs described do not seem to have repeated motifs (Burnside et al. 1989, Bodenner et al. 1991, Carr \& Wong 1994, Hollenberg et al. 1995, Yen 2001), making it improbable that classic heterodimers could bind these response elements.

The importance of coregulators has been well described for pTREs, while both the involvement and mechanisms of action are still poorly defined for nTREs (Yen 2001). Some studies have suggested the implication of the NcoR corepressor and histone acetylation in negative regulation of the TSH $\alpha$ promoter by TRs (Tagami et al. 1997, 1999). Although the mechanism is not clearly defined, it does not seem to involve a direct interaction of the receptors with DNA. On the other hand, NcoRI, which is devoid of repression domains, has been shown to enhance LIA of a $\mathrm{TRH}$ reporter by $\mathrm{TR} \alpha \mathrm{l}$ and $\mathrm{TR} \beta 1$ receptor (Hollenberg et al. 1996). Conformational changes of RXR upon heterodimerization with the TR have been shown to modify the conformation of helix 12 of the RXR and to unmask a corepressor-binding site (Zhang et al. 1999). The absence of DNAbinding of RXR, observed in our study, is not expected to have profound effects on the conformation of both receptors although it may modify their interactions with coactivators and corepressors. However, the fact that the effect of RXR on negative regulation is preserved with the use of the RXR AF-2 mutant (RXR E453A), a mutant previously shown not to bind coactivators, suggests that the effect observed is independent of coactivator binding (McKenna et al. 1999). To clarify the molecular mechanism of negative regulation of genes by $\mathrm{TRs}$, the interactions between coregulators and the TR-RXR complex should be studied further.

One other potential mechanism that could explain the RXR's role in negative regulation may be by direct interaction with the TATA-binding protein via its $\mathrm{AF}-2$ region, thereby mediating hormone-dependent transactivation, as previously described (Schulman et al. 1995). To verify this, we used the AF-2 mutant of RXR, E453A, which has previously been shown to lack AF-2 function (Liu et al. 1998). This mutant and $\operatorname{RXR} \alpha$ had similar activity in our system, suggesting that the AF-2 domain of RXR is not implicated in negative regulation by thyroid hormone.

Finally, we have demonstrated that thyroid hormone receptor DNA-binding is required for transcriptional repression of genes of the hypothalamo-pituitary axis (Fig. 7B). There is still controversy regarding the mechanism underlying negative regulation by thyroid hormone. One hypothesis suggests that negative regulation takes place in solution by squelching of transcription factors (Tagami et al. 1997). Another hypothesis, supported by this report, implicates DNA binding of thyroid hormone receptor on their differently configured negative response elements.

In conclusion, the data presented here confirm the importance of RXR in the negative regulation of the TRH and TSH genes by thyroid hormone. The data also delineate a new model of interaction between TR and RXR on these negatively regulated promoters. In this new model, TR interacts with the $\mathrm{C}$-terminus of RXR, without any binding of the RXR moiety to DNA. Therefore, on these negatively regulated genes, RXR behaves as a coregulator instead of a classic heterodimerization partner.

\section{Acknowledgements}

This work has been supported in part by grants and scholarships from the Banting Foundation, Medical Research Council of Canada (15655) and Fonds de 
Recherche en Santé du Québec to M-F L and by a scholarship from the Thyroid Foundation of Canada to L L. This work was presented in part at the 70th Annual Meeting of the American Thyroid Association, 2000 CDA/CSEM Annual Meeting and the 11th International Congress of Endocrinology. We would like to thank Dr Fredric E Wondisford for plasmids, fruitful discussions and the critical review of this manuscript. We would also like to thank Dr P Chambon for cDNAs of $\operatorname{RXR} \beta$ and $\operatorname{RXR} \gamma$.

\section{References}

Abel ED, Ahima RS, Boers ME, Elmquist JK \& Wondisford FE 2001 Critical role for thyroid hormone receptor beta2 in the regulation of paraventricular thyrotropin-releasing hormone neurons. Fournal of Clinical Investigation 107 1017-1023.

Bodenner DL, Mroczynski MA, Weintraub BD, Radovick S \& Wondisford FE 1991 A detailed functional and structural analysis of a major thyroid hormone inhibitory element in the human thyrotropin $\beta$-subunit gene. Fournal of Biological Chemistry 266 21666-21673.

Breathnach R \& Harris BA 1983 Plasmids for the cloning and expression of full-length double-stranded cDNAs under control of the SV40 early or late gene promoter. Nucleic Acids Research $\mathbf{1 1}$ 7119-7136.

Burnside J, Darling DS, Carr FE \& Chin WW 1989 Thyroid hormone regulation of the rat glycoprotein alpha-subunit gene promoter activity. Fournal of Biological Chemistry 264 6886-6891.

Carr FE \& Wong NC 1994 Characteristics of a negative thyroid hormone response element. Fournal of Biological Chemistry $\mathbf{2 6 9}$ $4175-4179$

Chatterjee VK, Lee JK, Rentoumis A \& Jameson JL 1989 Negative regulation of the thyroid-stimulating hormone alpha gene by thyroid hormone: receptor interaction adjacent to the TATA box. PNAS $869114-9118$.

Desvergne B, Petty KJ \& Nikodem VM 1991 Functional characterization and receptor binding studies of the malic enzyme thyroid hormone response element. Fournal of Biological Chemistry $2661008-1013$.

Gick GG \& Ismail-Beigi F 1990 Thyroid hormone induction of $\mathrm{Na}^{+}-\mathrm{K}^{+}$-ATPase and its mRNAs in a rat liver cell line. American Fournal of Physiology 258 C544 C551.

Glass CK, Franco R, Weinberger C, Albert V, Evans RM \& Rosenfeld MG 1987 A c-erb-A binding site in rat growth hormone gene mediates trans-activation by thyroid hormone. Nature 329 738-741.

Guibourdenche J, Roulier S, Rochette-Egly C \& Evain-Brion D 1998 High retinoid X receptor expression in JEG-3 choriocarcinoma cells: involvment in cell function modulation by retinoids. Fournal of Cellular Physiology 176 595-601.

Hallenbeck PL, Phyillaier M \& Nikodem VM 1993 Divergent effects of 9-cis-retinoic acid receptor on positive and negative thyroid hormone receptor-dependent gene expression. Fournal of Biological Chemistry 268 3825-3828.

Hamada K, Gleason SL, Levi B-Z, Hirschfeld S, Appella E \& Ozato K 1989 H-2 RIIBP, a member of the nuclear hormone receptor superfamily that binds to the regulatory element of major histocompatibility class I genes and the estrogen response element. PNAS 86 8289-8293.
Hartong R, Wang N, Kurokawa R, Lazar MA, Glass CK, Apriletti JW \& Dillman WH 1994 Delineation of three different thyroid hormone-response elements in promoter of rat sarcoplasmic reticulum $\mathrm{Ca}^{2+}$ ATPase gene. Fournal of Biological Chemistry $\mathbf{2 6 9}$ 13021-13029.

Haugen BR, Brown NS, Wood WM, Gordon DF \& Ridgway EC 1997 The thyrotrope-restricted isoform of the retinoid-X receptor- $\gamma 1$ mediates 9-cis-retinoic acid suppression of thyrotropin- $\beta$ promoter activity. Molecular Endocrinology 11 481-489.

Hodin RA, Lazar MA, Wintman BI, Darling DS, Koenig RJ, Larsen PR, Moore DD \& Chin WW 1989 Identification of a thyroid hormone receptor that is pituitary-specific. Science 24 76-79.

Hollenberg AN, Monden T, Flynn TR, Boers ME, Cohen O \& Wondisford FE 1995 The human thyrotropin-releasing gene is regulated by thyroid hormone through two distinct classes of negative thyroid hormone response elements. Molecular Endocrinology 9 540-550.

Hollenberg AN, Monden T, Madura JP, Lee K \& Wondisford FE 1996 Function of nuclear co-repressor protein on thyroid hormone response elements is regulated by the receptor A/B domain. Fournal of Biological Chemistry 271 28516-28520.

Hsu JH, Zavacki AM, Harney JW \& Brent GA 1995 Retinoid X receptor (RXR) differentially augments thyroid hormone response in cell lines as a function of the response element and endogenous RXR content. Endocrinology 136 421-430.

Katz RW \& Koenig RJ 1994 Specificity and mechanism of thyroid hormone induction from an octamer response element. Fournal of Biological Chemistry 269 18915-18920.

Koenig RJ, Lazar MA, Hodin RA, Brent GA, Larsen PR, Chin WW \& Moore DD 1989 Inhibition of thyroid hormone action by a non-hormone binding c-erbA protein generated by alternative mRNA splicing. Nature $337659-661$.

Kurlandsky SB, Xiao J-H, Duell EA, Voorhees JJ \& Fisher GJ 1994 Biological activity of all-trans retinol requires metabolic conversion to all-trans retinoic acid and is mediated through activation of nuclear retinoid receptors in human keratinocytes. Fournal of Biological Chemistry 269 32821-32827.

Langlois MF, Zanger K, Monden T, Safer JD, Hollenberg AN \& Wondisford FE 1997 A unique role of the $\beta 2$ thyroid hormone receptor isoform in negative regulation by thyroid hormone mapping of a novel amino-terminal domain important for ligandindependent activation. Fournal of Biological Chemistry 272 24927-24933.

Lechan RM, Qi Y, Berrodin TJ, Davis KD, Schwartz HL, Strait KA, Oppenheimer JH \& Lazar MA 1993 Immunocytochemical delineation of thyroid hormone receptor $\beta 2$-like immunoreactivity in the rat central nervous system. Endocrinology 132 2461-2469.

Lechan RM, Qi Y, Jackson IMD \& Mahdavi V 1994 Identification of thyroid hormone receptor isoforms in thyrotropin-releasing hormone neurons of the hypothalamic paraventricular nucleus. Endocrinology 135 92-100.

Leid M, Kastner P, Lyons R, Nakshatri H, Saunders M, Zacharewski T, Chen J-Y, Staub A, Garnier J-M, Mader S \& Chambon P 1992 Purification, cloning, and RXR identity of the Hela cell factor with which RAR or TR heterodimerizes to bind target sequences efficiently. Cell 68 377-395.

Leng X, Blanco J, Tsai SY, Ozato K, O’Mailley BW \& Tsai MJ 1994 Mechanisms for synergistic activation of thyroid hormone receptor and retinoid X receptor on different response elements. Fournal of Biological Chemistry 269 31436-31442.

Li M \& Boyages SC 1996 Detection of extended distribution of $\beta 2$-thyroid hormone receptor messenger RNA in adult rat brain using complementary RNA in situ hybridization histochemistry. Endocrinology 137 1272-1275.

Liu RT, Suzuki S, Miyamoto T, Takeda T, Ozata M \& DeGroot LJ 1995 The dominant negative effect of thyroid hormone receptor 
splicing variant $\alpha 2$ does not require binding to a thyroid response element. Molecular Endocrinology 9 86-95.

Liu Y, Takeshita A, Nagaya T, Baniahmad A, Chin WW \& Yen PM 1998 An inhibitory region of the DNA-binding domain of thyroid hormone receptor blocks hormone-dependent transactivation. Molecular Endocrinology $1234-44$.

McKenna NJ, Lanz RB \& O’Malley BW 1999 Nuclear receptor coregulators: cellular and molecular biology. Endocrine Revieres 20 321-344.

Mangelsdorf DJ \& Evans RM 1995 The RXR heterodimers and orphan receptors. Cell $\mathbf{8 3} 841-850$.

Mangelsdorf DJ, Ong ES, Dyck JA \& Evans RM 1990 Nuclear receptor that identifies a novel retinoic acid response pathway. Nature 355 441-446.

Mangelsdorf DJ, Borgmeyer U, Heyman RA, Zhou JY, Ong ES, Oro AE, Kakizuka A \& Evans RM 1992 Characterization of three RXR genes that mediate action of 9-cis retinoic acid. Genes and Development 6 329-344.

Nelson CG, Hendy SC, Faris JS \& Romaniuk PJ 1996 Retinoid X receptor alters the determination of DNA-binding specificity by the P-box amino acids of the thyroid hormone receptor. Fournal of Biological Chemistry 271 19464-19474.

Rosen ED, O’Donnell AL \& Koenig RJ 1992 Ligand-dependent synergy of thyroid hormone and retinoid $\mathrm{X}$ receptors. Fournal of Biological Chemistry 267 22010-22013.

Safer JD, Langlois MF, Cohen R, Monden T, John-Hope D, Madura J, Hollenberg AN \& Wondisford FE 1997 Isoform variable action among thyroid hormone receptor mutants provides insight into pituitary resistance to thyroid hormone. Molecular Endocrinology 11 16-26.

Sakurai A, Nakai A \& DeGroot LJ 1989 Expression of three forms of thyroid hormone receptor in human tissues. Molecular Endocrinology 3 392-399.

Sanno N, Sugawara A, Teramoto A, Abe Y, Yen PM, Chin WW \& Osamura RY 1997 Immunohistochemical expression of retinoid $\mathrm{X}$ receptor isoforms in human pituitaries and pituitary adenomas. Neuroendocrinology 65 299-306.

Schulman IG, Chakravarti D, Juguillon H, Romo A \& Evans RM 1995 Interactions between the retinoid X receptor and a conserved region of the TATA-binding protein mediate hormonedependent transactivation. PNAS 92 8288-8292.

Schwartz HL, Strait KA, Ling NC \& Oppenheimer JH 1992 Quantitation of rat tissue thyroid hormone binding receptor isoforms by immunoprecipitation of nuclear triiodothyronine binding capacity. Fournal of Biological Chemistry 267 11794-11799.
Schwartz HL, Lazar MA \& Oppenheimer JH 1994 Widespread distribution of immunoreactive TR $\beta 2$ in the nuclei of extrapituitary rat tissues. Foumal of Biological Chemistry 269 24777-24782.

Sugawara A, Yen PM, Qi Y, Lechan RM \& Chin WW 1995 Isoform-specific retinoid-X receptor (RXR) antibodies detect differential expression of RXR proteins in the pituitary gland. Endocrinology 136 1766-1774.

Tagami T, Madison LD, Nagaya T \& Jameson JL 1997 Nuclear receptor corepressors activate rather than suppress basal transcription of genes that are negatively regulated by thyroid hormone. Molecular and Cellular Biology 17 2642-2648.

Tagami T, Park Y \& Jameson JL 1999 Mechanisms that mediate negative regulation of the thyroid-stimulating hormone $\alpha$ gene by thyroid hormone receptor. Fournal of Biological Chemistry $\mathbf{2 7 4}$ 22345-22353.

Takeda T, Nagasawa T, Miyamoto T, Hashizume K \& DeGroot LJ 1997 The function of retinoid X receptors on negative thyroid hormone response elements. Molecular and Cellular Endocrinology 128 85-96.

Wondisford FE, Farr EA, Radovick S, Steinfelder HJ, Moates JM, McClaskey JH \& Weintraub BD 1989 Thyroid hormone inhibition of human thyrotropin $\beta$-subunit gene expression is mediated by a cis-acting element located in the first exon. Fournal of Biological Chemistry 264 14601-14604.

Wood WM, Dowding JM, Haugen BR, Bright TM, Gordon DF \& Ridgway EC 1994 Structural and functional characterization of the genomic locus encoding the murine $\beta 2$ thyroid hormone receptor. Molecular Endocrinology 8 1605-1617.

Yang Z, Hong SH \& Privalsky ML 1999 Transcriptional antirepression. Thyroid hormone receptor beta-2 recruits SMRT corepressor but interferes with subsequent assembly of a functional corepressor complex. Fournal of Biological Chemistry $\mathbf{2 7 4}$ 37131-37138.

Yen PM 2001 Physiological and molecular basis of thyroid hormone action. Physiological Reviewes 81 1097-1142.

Zhang XK, Hoffman B, Tran PB, Graupner G \& Pfahl M 1992 Retinoid X receptor is an auxiliary protein for thyroid hormone and retinoic acid receptors. Nature 355 441-446.

Zhang XK, Hu X \& Lazar MA 1999 A novel role for helix 12 of retinoid X receptor in regulating repression. Molecular and Cellular Biology 19 6448-6457.

Received in final form 11 April 2002

Accepted 25 April 2002 